\title{
IDENTIFIKASI DNA DARI SWAB EARPHONE DENGAN TEKNIK STR (SHORT TANDEM REPEAT) UNTUK KEPENTINGAN FORENSIK
}

\author{
Anindita Riesti Retno Arimurti*1, Ahmad Yudianto ${ }^{2}$, Sri Puji Astuti W. ${ }^{3}$ \\ ${ }^{1,2,3}$ Universitas Airlangga; Jl. Airlangga, Surabaya; (031) 5041566, 5041536 \\ ${ }^{1,2,3}$ Program Studi S2 Ilmu Forensik, Sekolah Pascasarjana, Universitas Airlangga, Surabaya \\ e-mail:*1aninditariesti@yahoo.com,+62 819890405
}

\begin{abstract}
Abstrak
Pemeriksaan DNA dalam dunia forensik dapat menggunakan cairan tubuh antara lain yaitu saliva, darah, sperma, semen, dan urine. Selain cairan tubuh, dapat juga menggunakan jaringan otot, gigi, dan tulang. Analisis DNA selain berasal dari tubuh manusia itu sendiri, dapat juga berasal dari benda - benda yang ditemukan di Tempat Kejadian Perkara (TKP) yang digunakan sebagai bahan pembanding. Contoh benda yang dapat digunakan sebagai barang bukti antara lain pakaian bekas dipakai, sprei, bahkan earphone. Dari benda - benda tersebut dapat diisolasi sel dan dianalisis DNA untuk mendapatkan keterangan lebih lanjut (Andarini, 2011). Sejauh ini pemeriksaan swab DNA yang berasal dari earphone dengan menggunakan teknik STR belum banyak dilakukan di Indonesia. Penelitian ini bertujuan untuk menganalisis DNA yang berasal dari swab earphone dengan metode STR dan perlakuan perbedaan waktu swab earphone. Lokus yang diperiksa pada penelitian ini D18S51 dan D21S11, karena lokus lokus tersebut memiliki daya deskriminasi besar pada populasi di Indonesia (Untoro, et al., 2009). Adanya perbedaan waktu swab earphone menyebabkan penurunan kadar DNA dan kemurniannya. Sedangkan untuk hasil elektroforesis, lokus D18S51 bagus untuk analisis DNA dari swab earphone, sedangkan lokus D21S11 kurang cocok karena hasil yang didapat pita DNAnya sangat tipis, hal ini disebabkan karena beberapa faktor salah satunya lokus D21S11 sudah terdegradasi.
\end{abstract}

Kata kunci : DNA, earphone, STR, lokus, D18S51, D21S11

\begin{abstract}
Examination of DNA in forensic can use fluids from a body which are, saliva, blood, sperm, semen, and urine. Aside from body fluids, it can also come from muscle tissues, teeth, and bones and besides from a human body, the objects which founded at the crime scene (TKP) can also be analyzed.

Thus, we can use them as a comparison. The examples of objects that can be use as evidences are used clothes, bed linen, or even earphones.

Mentioned objects could be isolated and DNA analyzed to obtain further information (Nadarini, 2011), until now swab examination of the DNA coming from earphones with an STR method has not been widely practiced in Indonesia.

The aim of this research is to analyze the DNA derived from earphones swab with an STR method and the handling of earphones swab time differences.

Locus examined in this research are D18S51 and D21S11, because these locus has a major discrimination to Indonesian population (Untoro, et al., 2009).
\end{abstract}


Jurnal Biosains Pascasarjana Vol. 17 (2015) pp

(C) (2015) Program Pascasarjana Universitas Airlangga, Indonesia

Earphone swab time difference causes decreased levels of DNA and its purity. As for the electrophoresis results D18S51 locus is good for earphone swab DNA analysis, while locus D21S11 is less suitable because the DNA tape is very thin, this was due to several factors; and one of the cause is degraded D21S11 locus.

Keywords : DNA, earphone, STR, locus, D18S51, D21S11

\section{PENDAHULUAN}

Pemeriksaan DNA banyak macamnya, antara lain yaitu RFLP (Restriction Fragment Length Polymorphism), VNTR (Variable Number Tandem Repeat), mt-DNA (Mitochondrial DNA), SNP (Single Nucleotide. Polymorphisms), STR (Short Tandem Repeat). Dalam dunia forensik, teknik pemeriksaan DNA yang paling sering dilakukan adalah STR, yaitu suatu metode biologi molekuler yang digunakan untuk membandingkan lokus tertentu pada DNA dari dua atau lebih sampel. Short Tandem Repeat merupakan teknik DNA profiling yang sering digunakan karena teknik ini cukup mudah, hanya memerlukan minimal 13 lokus sebagai pembanding. Ketigabelas lokus yang dianjurkan FBI antara lain yaitu TH01, TPOX, CSF1P0, vWA, FGA, D3S1358, D5S818, D7S820, D13S317, D16S539, D8S1179, D18S51, D21S11, dan ditambah dengan penanda amelogenin yang digunakan untuk analisis jenis kelamin (Butler et al., 2003).

Ukuran fragmen STR biasanya tidak lebih dari $500 \mathrm{bp}$, oleh karena itu STR dapat diamplifikasi dengan menggunakan jumlah DNA template yang relatif sedikit $( \pm 1 n g)$ dan juga dapat digunakan untuk menganalisa sampel DNA yang sudah terdegradasi (Kusumadewi, 2012).

Analisis DNA profiling dapat menggunakan bagian tubuh korban, antara lain yaitu darah, sperma, rambut, otot, gigi, bahkan tulang. Akan tetapi selain dari bagian tubuh manusia, sampel DNA bisa berasal dari barang - barang yang ada di TKP, contoh : baju bekas pakai, sikat gigi bekas pakai, earphone, dll. Akhir - akhir ini semakin banyak orang yang menggunakan earphone, oleh karena itu earphone dapat digunakan sebagai alternatif barang bukti untuk dianalisis DNA.

Sejauh ini pemeriksaan swab DNA yang berasal dari earphone dengan menggunakan teknik STR belum banyak dilakukan di Indonesia. Penelitian ini bertujuan untuk menganalisis DNA yang berasal dari swab earphone dengan menggunakan metode STR dan perlakuan perbedaan waktu swab sampel DNA. Lokus yang diperiksa pada penelitian ini antara lain D18S51 dan D21S11, karena kedua lokus tersebut yang memiliki daya deskriminasi besar pada populasi di Indonesia (Untoro, et al., 2009).

Waktu pengambilan swab DNA yang digunakan yaitu 1, 3, dan 5 hari, dengan alasan karena sel - sel apitel yang berada di earphone sangat sedikit, apabila terlalu lama tidak didapatkan DNA karena DNA telah terdegradasi seluruhnya. Adanya rentang waktu pengambilan swab DNA karena untuk mengetahui dengan berkurangnya kadar DNA, tetap bisa dianalisis dan diidentifikasi.

\section{Tinjauan Pustaka}

\subsection{Anatomi Telinga}

Telinga merupakan organ penting bagi manusia dan termasuk dalam panca indra. Telinga merupakan organ yang berperan terhadap pendengaran kita untuk mendeteksi suara atau bunyi, hal ini dapat terjadi karena telinga memiliki reseptor khusus yang berfungsi untuk mengenali getaran suara. Namun telinga memiliki batasan frekuensi suara yang dapat didengar, yaitu yang frekuensinya $20 \mathrm{~Hz}-20.000 \mathrm{~Hz}$. Telinga berfungsi sebagai indra pendengaran dan organ yang menjaga keseimbangan (Mills et al., 2006).

Pada bagian eksterior telinga, kanalis auditorius eksternal memiliki beberapa helai rambut halus dan kelenjar minyak yang disebut ceruminous glands yang mensekresi earwax atau serumen. Rambut - rambut halus dan serumen ini mencegah masuknya debu dan benda asing masuk kedalam telinga. Serumen biasanya mengering dan keluar dari kanal telinga (Tortora \& Derrickson, 2009).

Serumen adalah sekret kelenjar sebasea dan apokrin yang terdapat pada bagian kartilago telinga yang memiliki fungsi sebagai pelindung kanalis auditorius eksternal dari kerusakan oleh air, infeksi, trauma dan benda asing. Jumlah serumen yang terbentuk dan konsistensinya sangat bervariasi. Serumen juga berfungsi sebagai pelumas dan dapat mencegah kekeringan didalam telinga. Pada keadaan normal serumen tidak akan tertumpuk di liang telinga, tetapi akan keluar sendiri pada waktu mengunyah dan 
setelah sampai diluar liang telinga akan menguap oleh panas. Penumpukan serumen yang berlebihan akan menimbulkan gangguan pendengaran (Dinces, 2012).

\subsection{Earphone}

Earphone atau dalam bahasa Indonesia dikenal dengan nama penyuara kuping (bidang fisika dan elektronika) atau piranti dengar (bidang komunikasi massa) atau pelantang telinga (bidang umum) adalah sepasang pengeras suara kecil yang digunakan sangat dekat dengan telinga. Alat ini biasanya dihubungkan dengan alat komunikasi seperti handphone. Earphone digunakan sebagai alat bantu dengar telinga untuk telepon sebenarnya sudah ada sejak abad ke-20 (Alten, 2011).

Earphone dapat dijadikan salah satu barang bukti karena pada earphone yang telah digunakan, terdapat sel-sel epitel dari telinga dan serumen. Didalam sel-sel epitel dan serumen tersebut mengandung informasi genetik yang dapat dianalisis dan diidentifikasi.

\subsection{DNA (Deoxyribo Nucleic Acid)}

DNA (Deoxyribo Nucleic Acid) adalah senyawa kimia yang membawa informasi genetik pada tiap individu dan akan diturunkan ke keturunannya. Deoxyribo Nucleic Acid berbentuk untaian ganda (double helix). DNA di dalam sel mempunyai fungsi autokatalitis, yaitu DNA dapat mensintesis dirinya sendiri, proses ini biasa disebut replikasi. Fungsi lain DNA adalah heterokatalitis yang terdiri dari proses transkripsi, dan translasi. Ketiganya tersebut biasa disebut dogma sentral aliran genetik (Suryo, 2004).

Replikasi adalah proses penggandaan DNA dari DNA yang telah ada, sehingga masing - masing dari dua sel anak mewarisi genom lengkap dari sel induk. Proses transkripsi adalah pembentukan molekul RNA dari DNA. Rantai ganda DNA diubah menjadi rantai tunggal kemudian hanya satu rantai DNA yang akan menjadi template untuk pembentukan RNA. Setelah proses transkripsi dilanjutkan proses translasi, yaitu penyusunan protein dari sequence asam amino berdasarkan urutan basa nukleotida yang dibaca dari mRNA (Sutarno, 2010). Dalam proses translasi, setiap tiga basa nitrogen akan diterjemahkan sebagai satu molekul asam amino penyusun protein, contoh : start codon dikode ATG merupakan kode penyandi asam amino Metionin (MET), stop codon dikode TAA, TGA, dan TAG, asam amino Leusin (LEU) dikode CTT, dsb (Neto and Lapis, 2009).

Kode genetik berlaku universal, artinya kode yang sama berlaku untuk semua organisme. Oleh karena itu, urutan kode genetik mendefinisikan banyak hal, mulai dari jenis organisme sampai ciri - ciri fisik (fenotip) khusus tiap individu. Selain itu, kode genetik tersebut digunakan juga dalam analisis mutasi yang menyebabkan penyakit - penyakit genetik serta pengobatan yang tepat, rekayasa genetika untuk mendapatkan individu dengan sifat pilihan (Robinson ${ }^{1}$, 2003).

Dalam dunia forensik, kode genetik digunakan untuk analisis hubungan kekerabatan dan identifikasi individu. Selain itu sekarang ini sedang dikembangkan prediksi usia dari sekuens kode genetik DNA metilasi (Frumkin et al., 2011).

\subsection{Short Tandem Repeats (STRs)}

STRs (Short Tandem Repeats) adalah salah satu metode analisis yang berdasarkan pada metode Polymerase Chain Reaction (PCR). STRs adalah suatu analisis genetik yang digunakan untuk menggambarkan urutan DNA pendek (2-7 pasangan basa) yang diulang - ulang. Genom setiap manusia mengandung ratusan STRs. Metode ini paling banyak dikembangkan karena metode ini cepat, otomatis dan memiliki kekuatan diskriminasi yang tinggi (Butler, 2015).

Dengan metode STRs dapat memeriksa sampel DNA yang rusak atau dibawah standar karena ukuran fragmen DNA yang diperbanyak oleh PCR berkisar antara 200 - 500 pasangan basa.

Interpretasi data STR biasanya dimulai dengan melihat profil DNA secara keseluruhan dan didalam dunia forensik lokus yang diperiksa yaitu 13 lokus (Alonso, 2012 dan Butler, 2012). Lokus yang telah ditetapkan FBI sebagai acuan identifikasi forensik antara lain yaitu : CSF1P0, FGA, TH01, TPOX, vWA, D3S1358, D5S818, D7S820, D8S1179, D13S317, D16S539, D18S51, D21S11, dan penanda amelogenin yang digunakan dalam analisis jenis kelamin (Butler et al., 2003).

Setiap lokus STR mempunyai ciri-ciri khusus (Tabel 2.1.). Dan setiap lokus STR tersebut, tiap - tiap individu mempunyai dua fragmen DNA yang masing - masing diturunkan dari orang tuanya. Oleh karena itu, semakin banyak lokus STR yang diperiksa maka semakin spesifik mengarah pada satu individu (Notosoehardjo dan Pudjiwitomo, 2009).

Tabel 1. Informasi karakterisasi lokus STR (Butler \& Hill, 2012)

\begin{tabular}{cccc}
\hline Lokus STR & Lokasi & Repeat Motif & Ukuran PCR Produk (bp) \\
\hline CSF1P0 & 5q33.1 & AGAT & $321-357$ \\
\hline FGA & 4q31.3 & CTTT/TTCC & $322-444$ \\
\hline TH01 & $11 \mathrm{p} 15.5$ & TCAT & $156-195$ \\
\hline TPOX & 22p25.3 & AATG & $262-290$ \\
\hline vWA & $12 \mathrm{p} 13.31$ & TCTA / TCTG & $123-171$ \\
\hline D3S1358 & 3p21.31 & TCTA / TCTG & $115-147$ \\
\hline D5S818 & $5 q 23.2$ & AGAT & $119-155$ \\
\hline D7S820 & 7q21.11 & GATA & $215-247$ \\
\hline D8S1179 & 8q24.13 & TCTA / TCTG & $203-247$ \\
\hline D13S317 & $13 q 31.1$ & TATC & $169-201$ \\
\hline D16S539 & $16 q 24.1$ & GATA & $264-304$ \\
\hline D18SS51 & $18 q 21.33$ & AGAA & $290-366$ \\
\hline D21S11 & 21q21.1 & TCTA / TCTG & $203-259$ \\
\hline
\end{tabular}

Keterangan : Tiap-tiap lokus terletak pada kromosom tertentu dan memiliki daerah repeat yang berbeda - beda. Oleh 
karena itu, pemeriksaan analisis DNA dalam dunia forensik, menggunakan beberapa lokus agar semakin spesifik mengarah pada satu individu.

\section{METODE PENELITIAN}

\subsection{Alat dan bahan}

Alat yang digunakan dalam penelitian ini dibedakan menjadi dua macam, yaitu :

a. Alat untuk mengambil sampel sel epitel dan serumen telinga manusia antara lain earphone untuk digunakan oleh probandus kemudian sel-sel epitel dan serumen yang menempel di earphone diambil dengan cara swab. Tabung untuk menyimpan hasil swab. Serta kertas label atau spidol permanen untuk melabel sample sesuai dengan identitas probandus tersebut.

b. Sedangkan untuk analisis DNA digunakan, ultracentrifuge (Gyrozen Co., Ltd.), vortex mixer, refrigerator untuk menyimpan sampel, pipet mikro (eppendorf pippet) P10, P100, dan P1000, Thermal cycler PCR Machine (Boeco), elektroforator (Mini Run Gel Electrophoresis System GE-100), UV transilluminator (BioRad), ice box, microwave, inkubator, autoclave dan kamera digital untuk memfoto hasil elektroforesis.

Bahan yang digunakan untuk penelitian ini antara lain yaitu, sel-sel epitel manusia yang berasal dari telinga probandus manusia. Sedangkan bahan yang digunakan untuk analisis variasi genetik meliputi : Kit isolasi DNA ®Fermentas : GeneJET Genomic DNA Purification Kit, gel akrilamid 1,75\%, buffer TBE 1X, dan etidium bromide (EtBr), primer, PCR Kit ${ }^{\circledR}$ Fermentas (DreamTaq ${ }^{\mathrm{TM}}$ Green PCR Master Mix (2x)), ethanol 70\%, PBS, akuabides (water nukleasefree), akuades steril, alumunium foil, dan ladder DNA (marker) 100 - 3000 bp ®Vivantis.

\subsection{Cara kerja}

Earphone digunakan oleh sukarelawan selama tiga hari berturut-turut. Hari berikutnya, earphone dimasukan kedalam amplop kertas kemudian dikembalikan ke peneliti. Sehari setelahnya (dianggap sebagai hari ke-1), sebanyak 6 earphone diswab kemudian diisolasi DNAnya. Setelah itu disimpan pada suhu $-20^{\circ} \mathrm{C}$. Dua hari berikutnya (dianggap sebagai hari ke-3), sebanyak 6 sampel earphone diswab dan diisolasi DNAnya. Kemudian hasil isolasi DNA disimpan pada suhu $-20^{\circ} \mathrm{C}$. Enam (6) sampel earphone terakhir diswab dan diisolasi DNAnya pada dua hari berikutnya (dianggap sebagai hari kelima). Hasil isolasi DNA disimpan pada suhu - $20^{\circ} \mathrm{C}$ juga.

Hari berikutnya, semua sampel hasil isolasi DNA diuji kadar dan kemurniannya dengan spektrofotometer. Hasil spektrofotometri diurutkan dari DNA dengan kadar tertinggi hingga terendah pada tiap kelompok hari, kemudian dari tiap-tiap kelompok hari, diambil dua sampel dengan kadar tertinggi dan terendah untuk dianalisis selanjutnya.

Tahap selanjutnya yaitu amplifikasi DNA dengan metode PCR (Polymerase Chain Reacton). Adapun lokus yang diperiksa pada penelitian ini adalah D18S51 dan D21S11. Alasan pemilihan kedua lokus tersebut karena kedua lokus tersebut mempunyai daya diskriminasi tinggi pada populasi di Indonesia (Untoro, 2009). Suhu yang digunakan pada proses PCR ini sebagai berikut :

$\left.\begin{array}{ll}\text { Predenaturasi } & : 96^{\circ} \mathrm{C}-2 \text { menit } \\ \text { Denaturasi } & : 94^{\circ} \mathrm{C}-1 \text { menit } \\ \text { Annealing } & : 60^{\circ} \mathrm{C}-1 \text { menit } \\ \text { Extension } & : 70^{\circ} \mathrm{C}-1,5 \text { menit } \\ \hline \text { Denaturasi } & : 90^{\circ} \mathrm{C}-1 \text { menit } \\ \text { Annealing } & : 60^{\circ} \mathrm{C}-1 \text { menit } \\ \text { Extension } & : 70^{\circ} \mathrm{C}-1,5 \text { menit } \\ \text { Final extension } & : 60^{\circ} \mathrm{C}-30 \text { detik }\end{array}\right] 25 \mathrm{x}$ siklus

Adapun komposisi PCR yang digunakan sebagai berikut :

Primer $\quad: 2,5 \mu l$ (menggunakan 2 primer, jadi total $5 \mu \mathrm{l})$

PCR mix $\quad: 12,5 \mu l$

Sampel $\quad: 1 \mu 1$

Aquades steril $: 6 \mu 1$

Total volume $: 25 \mu \mathrm{l}$

Selain sampel DNA yang diamplifikasi, terdapat juga dua kontrol yang diamplifikasi juga, yaitu kontrol positif berupa K562 dan kontrol negatif berupa akuades steril.

Setelah PCR tahapan selanjutnya yaitu elektroforesis. Pada penelitian ini menggunakan gel akrilamid dan marker 100bp. Sebanyak $15 \mu \mathrm{l}$ sampel hasil PCR diambil lalu dimasukkan pada sumuran gel akrilamid. Kemudian dirunning selama 45 menit. Setelah itu, hasil elektroforesis direndam dengan pewarna silver stain selama \pm 30 menit kemudian diperiksa dibawah lampu dan hasilnya difoto dengan kamera digital.

\section{HASIL DAN PEMBAHASAN}

Hasil pemeriksaan kadar dan kemurnian DNA, didapatkan hasil sebagai berikut :

Tabel 2. Kadar DNA hasil swab earphone

\begin{tabular}{|c|c|c|c|c|}
\hline Hari & No. & Sampel ID & ng/ $\mu 1$ & $260 / 280$ \\
\hline \multirow{5}{*}{ Hari ke-1 } & 1 & $\mathrm{KA} / 23 / \mathrm{F}$ & 359.04 & 1.85 \\
\cline { 2 - 5 } & 2 & $\mathrm{FP} / 21 / \mathrm{M}$ & 305.17 & 1.88 \\
\cline { 2 - 5 } & 3 & $\mathrm{FAN} / 31 / \mathrm{M}$ & 200.4 & 1.76 \\
\cline { 2 - 5 } & 4 & $\mathrm{KAE} / 23 / \mathrm{F}$ & 193.32 & 1.75 \\
\cline { 2 - 5 } & 5 & $\mathrm{WDD} / 23 / \mathrm{F}$ & 190.44 & 1.76 \\
\cline { 2 - 5 } & 6 & $\mathrm{AMF} / 23 / \mathrm{M}$ & 187.28 & 1.79 \\
\hline \multirow{3}{*}{ Hari ke-3 } & 1 & $\mathrm{JA} / 44 / \mathrm{M}$ & 176.16 & 1.75 \\
\cline { 2 - 5 } & 2 & $\mathrm{JRZ} / 27 / \mathrm{M}$ & 162.56 & 1.74 \\
\hline
\end{tabular}


Jurnal Biosains Pascasarjana Vol. 17 (2015) pp

(C) (2015) Program Pascasarjana Universitas Airlangga, Indonesia

\begin{tabular}{|c|c|c|c|c|}
\hline \multirow{5}{*}{} & 3 & $\mathrm{KP} / 22 / \mathrm{F}$ & 162.25 & 1.72 \\
\cline { 2 - 5 } & 4 & $\mathrm{AHL} / 24 / \mathrm{F}$ & 160.92 & 1.74 \\
\cline { 2 - 5 } & 5 & $\mathrm{ETSM} / 31 / \mathrm{F}$ & 155.81 & 1.76 \\
\cline { 2 - 5 } Hari ke-5 & 6 & $\mathrm{RNF} / 28 / \mathrm{F}$ & 155.1 & 1.71 \\
\hline & 1 & $\mathrm{TP} / 22 / \mathrm{F}$ & 138.94 & 1.74 \\
\cline { 2 - 5 } & 2 & $\mathrm{ARRA} / 25 / \mathrm{F}$ & 120.58 & 1.73 \\
\cline { 2 - 5 } & 3 & $\mathrm{DB} / 25 / \mathrm{F}$ & 113.82 & 1.69 \\
\cline { 2 - 5 } & 4 & $\mathrm{RAE} / 24 / \mathrm{F}$ & 99.63 & 1.65 \\
\cline { 2 - 5 } & 5 & $\mathrm{AW} / 25 / \mathrm{F}$ & 97.11 & 1.65 \\
\cline { 2 - 5 } & 6 & $\mathrm{FA} / 33 / \mathrm{F}$ & 74.76 & 1.61 \\
\hline
\end{tabular}

Tabel 4. Hasil uji Kruskal Wallis kemurnian DNA Ranks

\begin{tabular}{|c|c|c|c|}
\hline & hari & $\mathrm{N}$ & Mean Rank \\
\hline \multirow{4}{*}{ Kemurnian } & harike-1 & 6 & 15.08 \\
\hline & harike-3 & 6 & 9.08 \\
\hline & harike-5 & 6 & 4.33 \\
\hline & Total & 18 & \\
\hline
\end{tabular}

kadar dan kemurnian DNA dari hasil swab earphone dengan perlakuan perbedaan hari swab. Sehingga dapat dinyatakan bahwa semakin lama waktu perlakuan diberikan atau dengan kata lain semakin lama earphone terpapar di lingkungan, maka terdapat kecenderungan kadar dan kemurnian DNA mengalami penurunan.

Untuk memastikan apakah ada pengaruh perbedaan waktu swab earphone dengan kadar DNA, maka dilakukan uji statistika yaitu Kruskal Wallis. Alasan digunakan uji statistika Kruskal Wallis karena data yang didapat tidak memenuhi uji statistika Anova, yaitu data tidak homogen.

Berikut hasil uji statistika dengan Kruskal Wallis :

Tabel 3. Hasil uji Kruskal Wallis kadar DNA

Ranks

\begin{tabular}{|l|r|r|r|}
\hline & hari & N & Mean Rank \\
\hline \multirow{3}{*}{ Kadar $\quad$ harike-1 } & 6 & 15.50 \\
& harike-3 & 6 & 9.50 \\
& harike-5 & 6 & 3.50 \\
& Total & 18 & \\
\hline
\end{tabular}

Test Statistics ${ }^{a b} \mathrm{~b}$

\begin{tabular}{|l|r|}
\hline & Kensentrasi \\
\hline Chi-Square & 15.158 \\
df & 2 \\
Asymp. Sig. & .001 \\
\hline
\end{tabular}

a. Kruskal Wallis Test

b. Grouping Variable: hari

\begin{tabular}{|c|c|}
\hline & Kemurnian \\
\hline Chi-Square & 12.347 \\
\hline $\mathrm{df}$ & 2 \\
\hline Asymp. Sig. & .002 \\
\hline
\end{tabular}

a. Kruskal Wallis Test

b. Grouping Variable: hari

Dari Tabel 4.2. diatas, hasil uji Kruskal Wallis untuk kadar DNA diperoleh nilai $\mathrm{p}$ (asymp.Sig.) = 0.001 . Oleh karena nilai $\mathrm{p}<0,05$, maka H0 ditolak dan Hi diterima, sehingga dapat disimpulkan bahwa ada pengaruh perbedaan waktu swab earphone terhadap kadar DNA yang didapatkan.

Dari Tabel 4.3. diatas, hasil uji Kruskal Wallis untuk kadar DNA diperoleh nilai $\mathrm{p}$ (asymp.Sig.) = 0.002. Oleh karena nilai $\mathrm{p}<0,05$ maka H0 ditolak dan Hi diterima, sehingga dapat disimpulkan bahwa ada pengaruh perbedaan waktu swab earphone terhadap kemurnian DNA yang didapatkan.

Untuk mengidentifikasi individu maka diperlukan pemeriksaan pada beberapa lokus dengan metode Short Tandem Repeat (STR). Pada penelitian ini lokus yang diperiksa antara lain yaitu D18S51 dan D21S11, karena ketiga lokus tersebut memiliki daya diskriminasi yang tinggi. Sampel yang dianalisis lokusnya yaitu sampel dengan kadar tertinggi dan terendah pada tiap - tiap perlakuan waktu. Sehingga untuk satu lokus ada enam (6) sampel yang diperiksa.

Lokus D18S51

Lokus pertama yang diperiksa pada penelitian ini adalah D18S51. Hasil visualisasi PCR lokus D18S51 sebagai berikut : 


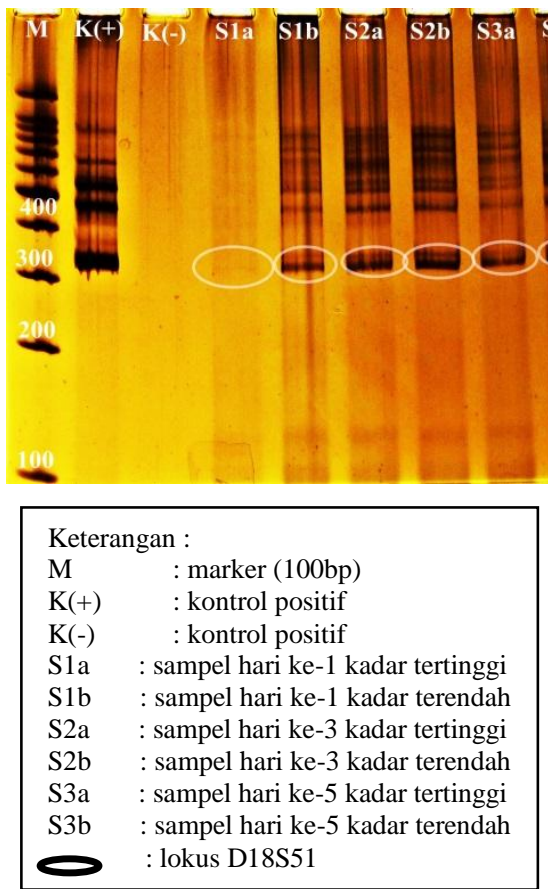

Gambar 1. Hasil visualisasi PCR lokus D18S51

Ukuran produk PCR (bp) untuk lokus D18S51 : 290 - 366. Gambar 4.1. diatas menunjukkan hasil amplifikasi PCR lokus D18S51 terhadap sampel swab earphone dari hari ke-1 sampai hari ke-5 terlihat pita atau band DNA.

Lokus D21S11

Lokus terakhir yang diperiksa pada penelitian ini adalah D21S11. Hasil visualisasi PCR lokus D21S11 sebagai berikut :

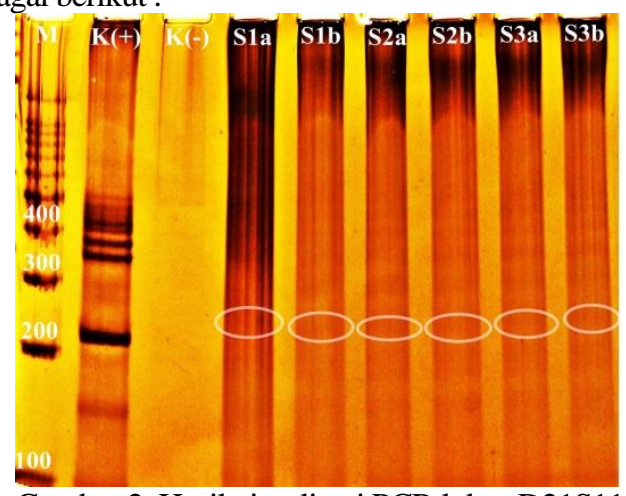

Gambar 2. Hasil visualisasi PCR lokus D21S11

\begin{tabular}{|ll|}
\hline \multicolumn{2}{|l|}{ Keterangan : } \\
$\mathrm{M}$ & : marker (100bp) \\
$\mathrm{K}(+)$ & : kontrol positif \\
$\mathrm{K}(-)$ & : kontrol positif \\
S1a & : sampel hari ke-1 kadar tertinggi \\
S1b & : sampel hari ke-1 kadar terendah \\
S2a & : sampel hari ke-3 kadar tertinggi \\
S2b & : sampel hari ke-3 kadar terendah \\
S3a & : sampel hari ke-5 kadar tertinggi \\
S3b & : sampel hari ke-5 kadar terendah \\
O & : lokus D21S11 \\
\hline
\end{tabular}

Ukuran produk PCR (bp) untuk lokus D21S11 : 203 - 259. Gambar 4.2. diatas menunjukkan hasil amplifikasi PCR lokus D21S11 terhadap sampel swab earphone dari hari ke-1 sampai hari ke-5 terlihat pita atau band DNA.

\section{KESIMPULAN DAN SARAN}

Perbedaan waktu swab mengakibatkan penurunan kadar dan kemurnian DNA yang signifikan. Hasil visualisasi kedua lokus $100 \%$ muncul semua. Akan tetapi untuk lokus D21S11 hasilnya tidak sebagus lokus D18S51. Hal ini karena lokus D21S11 lebih banyak mengalami degradasi dari hasil swab earphone.

\section{ACUAN REFERENSI}

Alonso, A. 2012. DNA Electrophoresis Protocols For Forensic Genetics. Spain: Humana Press.

Alten, S. F. 2011. Cengage Advantage Books : Audio Basics 1st Edition. England: Wadsworth Publishing.

Andarini, M. 2011. Serologi Forensik. Yogyakarta: Gadjah Mada University Press.

Butler, J. M. 2015. Advanced Topics In Forensic DNA Typing: Interpretation. San Diego, USA: Academic Press, Elsevier.

Butler, J. M. \& Hill, C. R. 2012. Biology and Genetics of New Autosomal STR Loci Useful for Forensic DNA Analysis. Forensic Science Review, Vol: 24, No. 1.

Butler, J. M., Shen, Y., Bruce, R., and Mc. Cord. 2003. The Development of Reduced Size STR Amplicons As Tools for Analysis of Degraded DNA. Journal Forensic Science, Vol. 48 No. 5, pp: $1054-1064$.

Dinces, E. A. 2012. Cerumen. http:// androsma.5gbfree.com

/contents/mobipreview.htm?12/33/12823? source $=$ related_link. Diakses: 11 September 2015, Pukul 19.45 WIB.

Frumkin, D., Wasserstrom, A., Budowle, B., Davidson, A., 2011. DNA Methylationbased Forensic Tissue Identification. Forensic Science International: Genetics. Vol. 5 : 517 - 524.

Kusumadewi, A., Kusuma, S. E., dan Yudianto, A. 2012. Analisis DNA Jaringan Lunak Manusia yang Terpapar Formalin dalam Interval Waktu 1 Bulan Selama 6 Bulan pada Lokus D13S317 dengan Metode STR-PCR. Jurnal Biosains Unair Vol. 14, No.2. 
Jurnal Biosains Pascasarjana Vol. 17 (2015) pp

(C) (2015) Program Pascasarjana Universitas Airlangga, Indonesia

Mills, J. H., Khariwala, S. S., Weber, P. C. 2006. Anatomy And Physiology Of Hearing ; Head \& Neck Surgery Otolaryngology 4th Ed Vol.2. Philadelphia: J. B. Lippincot Co.

Neto, B. A. D. and Lapis, A. A. M. 2009. Recent Developments in the Chemistry of Deoxyribonucleic Acid (DNA) Intercalators: Principles, Design, Synthesis, Applications and Trends. Journal of Molecules. Vol. 14: 1725 1746; doi : 10.3390/molecules14051725.

Notosoehardjo, I dan Pudjiwitomo, K. 2009. Stabilitas DNA Post Mortem, Majalah Ilmu Kedokteran Forensik, Vol. VII No. 1. Surabaya. Hal: $31-37$.

Robinson ${ }^{1}$, R. 2003. Genetics Volume IV. New York, USA: Mac Millan Science Library. Pp: 12, $68-71$.

Suryo. 2004. Genetika Strata 1. Yogyakarta: Gadjah Mada University Press. Pp: 57 $66,73-75$.

Sutarno. 2010. Sintesis Protein. Surakarta: UNS Press.

Tortora, G. J., and Derrickson, B. 2009. Introduction to The Human Body: The Essentials of Anatomy and Physiology. USA: John Wiley \& Sons, Inc.

Untoro, E., Atmadja, D. S., Pu, C. W., Wu, F. C. 2009. Allele Frequency Of CODIS 13 In Indonesia Population. Legal Medicine 11: S203- 205. 